\title{
Difficult Conversations and Painful Decisions: When Should Patients with Progressive Cancer Stop Chemotherapy?
}

\author{
Jeanine Staples' ${ }^{1}$ Varvara Mazina², Bethany-Rose Daubman³, Annekathryn Goodman²* \\ ${ }^{1}$ Sibley Memorial Hospital, Johns Hopkins Medicine, Sibley Center for Gynecologic Oncology and Advanced Pelvic Surgery, \\ Washington, USA \\ ${ }^{2}$ Massachusetts General Hospital, Harvard Medical School, Division of Gynecologic Oncology, Boston, USA \\ ${ }^{3}$ Massachusetts General Hospital, Harvard Medical School, Division of Palliative Care and Geriatric Medicine, Boston, USA \\ Email: jstap110@jhmi.edu,vmazina@mgh.harvard.edu,bdaubman@mgh.harvard.edu, *agoodman@mgh.harvard.edu
}

How to cite this paper: Staples, J., Mazina, V., Daubman, B.-R. and Goodman, A. (2022) Difficult Conversations and Painful Decisions: When Should Patients with Progressive Cancer Stop Chemotherapy? Journal of Cancer Therapy, 13, 20-47. https://doi.org/10.4236/jct.2022.131003

Received: December 25, 2021

Accepted: January 21, 2022

Published: January 24, 2022

Copyright $\odot 2022$ by author(s) and Scientific Research Publishing Inc. This work is licensed under the Creative Commons Attribution International License (CC BY 4.0).

http://creativecommons.org/licenses/by/4.0/

\section{Open Access}

\begin{abstract}
Introduction: The decision to stop anti-cancer treatment is fraught with many challenges for the oncologist, the patient, and their caregivers. This review examines the special considerations surrounding the decision to cease chemotherapy in terminally ill cancer patient. Methods: A comprehensive literature search was conducted to find relevant publications on chemotherapy cessation. A total of 2700 records were retrieved and 141 were identified as eligible for inclusion in this review. Results: Palliative chemotherapy does not achieve the goal of tumor-related symptom reduction for patients who have experienced progressive disease with more than two prior lines of chemotherapy. ECOG performance status is a crucial predictor of response to therapy and chemotherapy-related complications. Challenges to stopping chemotherapy at the end of life are multifactorial and are both patient and physician-driven. Racial, ethnic, and income-based disparities are seen in the timing and quality of end-of-life conversations offered by physicians to their patients. Conclusions: The decision to cease chemotherapy is one that should be approached with careful consideration and accurate information. Clear communication, compassion and empathy are important components to the therapeutic relationship. Early involvement of palliative care and clear conversations about prognosis and the expected utility of further chemotherapy is essential to conduct the best possible care for cancer patients at the end of life.
\end{abstract}

\section{Keywords}

Chemotherapy, Chemotherapy Resistance, Chemotherapy Cessation, 
Palliative Chemotherapy, Recurrent Cancer and Prognosis, Best Supportive

Care, Medical Futility, End-of-Life

\section{Introduction}

Chemotherapy, a common modality for the treatment and management of cancer, is utilized for curative intent, the prolongation of life, and palliation of symptoms. While advances in treatment have led to increased survival and improved treatment outcomes, many patients will ultimately succumb to their disease. For patients with continued disease progression despite multiple lines of chemotherapy, discussions that treatment is no longer effective can be difficult. When chemotherapy is no longer effective, what is the appropriate next step in caring for the patient? What exactly does cessation of chemotherapy mean for the patient? How is such a decision made? There is a profound existential and emotional transition point between active treatment and best supportive care where goals of treatment are assessed, and the decision is made to withhold chemotherapy. There is little data addressing the various psychological, physical, and medical aspects of this unique turning point. This review examines the special considerations surrounding the decision to cease chemotherapy in terminally ill cancer patient.

\section{Methods}

A comprehensive literature search was conducted to find relevant publications on chemotherapy cessation. The search was conducted on the National Center for Biotechnology Information (NCBI) and PubMed (U.S. National Library of Medicine at the National Institutes of Health). The keywords used in the search included "chemotherapy", "chemotherapy resistance", "chemotherapy cessation", "palliative chemotherapy", "recurrent cancer and prognosis", "best supportive care", "medical futility", and "end-of-life."

Inclusion and exclusion criteria were applied to the abstracts of the resulting publications. Selected literature was then reviewed in its entirety for suitability. The inclusion criteria were as follows: studies of patients with advanced, incurable cancers, assessment of survival and quality of life (QOL) present, information about outcomes provided, information about patient or physician decision making given, published in English. No time-period limit was applied. Studies were excluded if they did not include information about outcomes, QOL, or patient decision-making. Figure 1 summarizes the Prisma diagram for this review.

\section{Chemotherapy at the End-of-Life}

Chemotherapy has been demonstrated across many disease sites to extend overall survival. Palliative chemotherapy is administered in circumstances where the impact of that intervention will not result in a survival advantage but may 


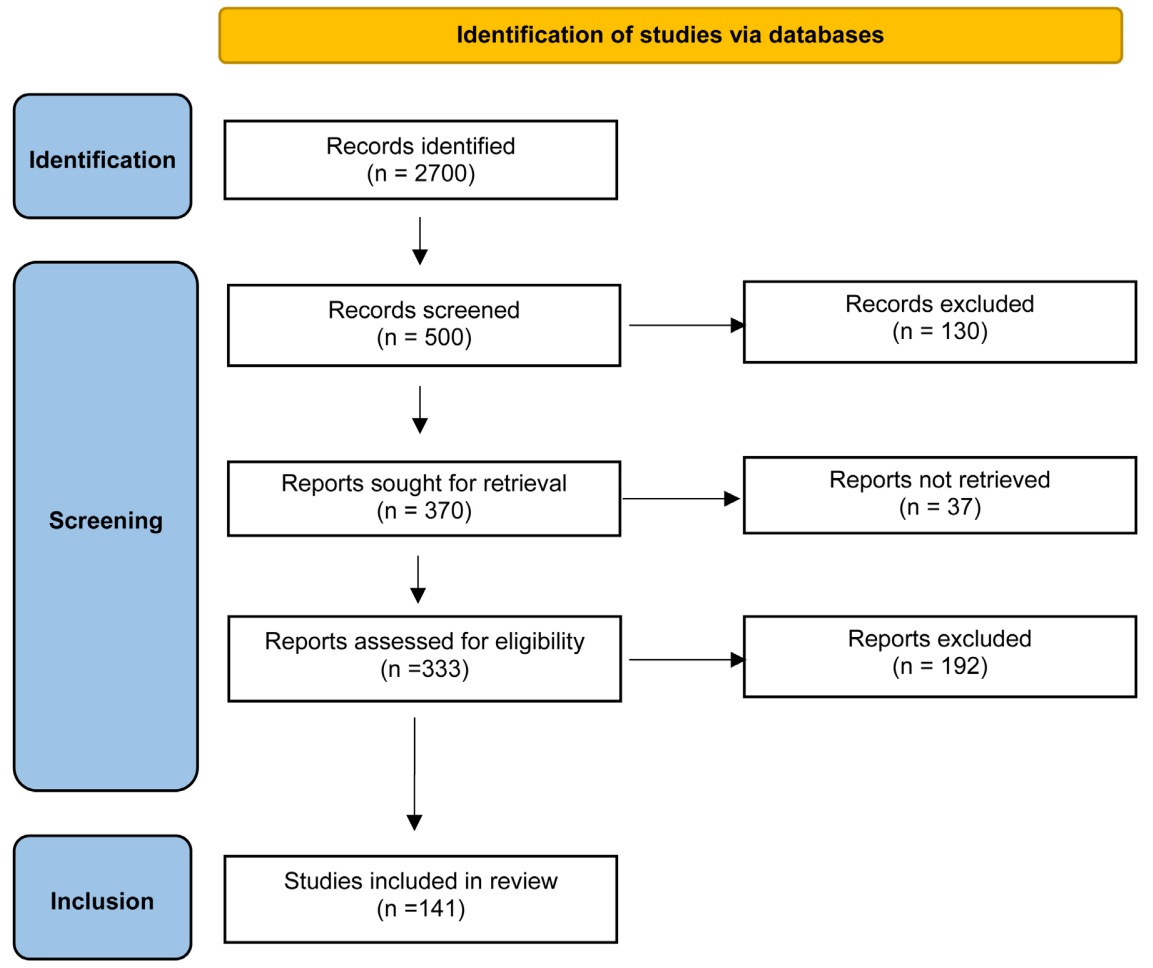

Figure 1. Prisma diagram for comprehensive literature search on chemotherapy cessation.

improve tumor-related symptoms and QOL [1] [2] [3]. Judicious administration of chemotherapy with palliative intent has the potential to provide symptom reduction via decrease or stabilization of the tumor burden [4]. However, along with the improvement in tumor-related symptoms, anti-cancer medications are associated with often severe adverse effects. Chemotherapy has some significant, cumulative, and occasionally irreversible toxicities [5]. Fatigue, anorexia, hair loss, peripheral neuropathy, nausea, and vomiting are just a few of the most common. Overall, chemotherapy is associated with a reduction in long-term QOL, especially in younger patients [6] [7] [8] [9]. Table 1 summarizes the more commonly encountered side effects of chemotherapy.

Given the high symptomatic cost of administration of chemotherapy, when survival benefits are ambiguous at best, the overall effect of administration of chemotherapy on QOL, and possibility of shortening, rather than prolonging survival, should be carefully considered and incorporated into final decisions on treatment [10] [20]. Patients receiving palliative chemotherapy may suffer harmful effects from these drugs which may decrease overall QOLe during their final months [21] [22]. QOL should be included in the assessment of treatment efficacy [23]. Carey et al. showed that good performance status and QOL both were predictive factors for improved progression-free and overall survival [24]. However, it is challenging to determine whether QOL is maintained or worsened by palliative chemotherapy. Defining the meaning and limits of this strategy in the practice setting is by no means a straightforward venture [25]. There is a 
Table 1. Adverse effects of anticancer medications.

\begin{tabular}{|c|c|c|}
\hline Body System & Comments & Mechanisms \\
\hline Neurologic [10] [11] & $\begin{array}{l}\text { Cognitive impairment } \\
\text { Peripheral neuropathy } \\
\text { Loss of proprioception }\end{array}$ & $\begin{array}{l}\text { Cytokine dysregulation } \\
\text { Damage to neuronal cell bodies in dorsal root ganglion } \\
\text { Axonal membrane ion channel dysfunction }\end{array}$ \\
\hline Psychiatric [12] & $\begin{array}{l}\text { Depression } \\
\text { Anxiety } \\
\text { Negative body image }\end{array}$ & $\begin{array}{l}\text { Inflammation } \\
\text { Hyperactive hypothalamic-pituitary-adrenal axis } \\
\text { Glutamate excitotoxicity }\end{array}$ \\
\hline Dermatologic [13] & $\begin{array}{l}\text { Alopecia } \\
\text { Rash } \\
\text { Plantar-palmar erythrodysesthesia } \\
\text { Allergy } \\
\text { Mouth sores } \\
\text { Discolored nails }\end{array}$ & $\begin{array}{l}\text { EGFR inhibition } \\
\text { Allergic IgE mediated reactions } \\
\text { Drug extravasation; direct damage } \\
\text { Increased expression of enzymes necessary for } \\
\text { capecitabine activation }\end{array}$ \\
\hline Pulmonary [14] & $\begin{array}{l}\text { Pneumonitis } \\
\text { Pulmonary fibrosis }\end{array}$ & $\begin{array}{l}\text { Proinflammatory cytokines: IL-6; IL-8; TMF } \\
\text { T-cell proliferation } \\
\text { Acute phase protein production } \\
\text { Infectious etiology: viral, bacterial, fungal }\end{array}$ \\
\hline Cardiac [15] & Cardiomyopathy & $\begin{array}{l}\text { Rapid apoptosis or necrosis of myocytes } \\
\text { Mitochondrial damage, changes in ATP production }\end{array}$ \\
\hline Gastrointestinal [16] & $\begin{array}{l}\text { Nausea and vomiting } \\
\text { Diarrhea } \\
\text { Constipation } \\
\text { Bowel fistulization/perforation }\end{array}$ & $\begin{array}{l}\text { Alterations in microbiome } \\
\text { Increases intestine wall permeability } \\
\text { Inflammatory responses }\end{array}$ \\
\hline Genito-urinary [17] & $\begin{array}{l}\text { Hemorrhagic cystitis } \\
\text { Sexual dysfunction } \\
\text { Renal failure }\end{array}$ & $\begin{array}{l}\text { Estrogen deficiency } \\
\text { Nephrotoxicity } \\
\text { Inflammatory response, reactive oxygen species, nitric } \\
\text { oxide production }\end{array}$ \\
\hline Hematologic [18] & $\begin{array}{l}\text { Bone marrow suppression } \\
\text { Myelodysplastic syndrome/secondary } \\
\text { leukemias }\end{array}$ & $\begin{array}{l}\text { Direct destruction of bone marrow populations } \\
\text { Quantitative reduction in hematopoietic stem cell (HSC) } \\
\text { due to apoptosis } \\
\text { Qualitative changes in HSC replicative function } \\
\text { Damage to bone marrow stromal cells }\end{array}$ \\
\hline Immunologic [19] & $\begin{array}{l}\text { Auto-immune syndromes from } \\
\text { immunotherapy }\end{array}$ & Enhanced activation of T-cells \\
\hline
\end{tabular}

very fine balance that incorporates the patient's health, their goals and values, as well as the capabilities and limitations of medicine. Finally, appropriately timed cessation of chemotherapy is integral to a patient's QOL [26] [27].

Studies from both the United States and Europe have documented the increasing propensity to use aggressive interventions near death, including chemotherapy in terminally ill cancer patients [1] [2] [3]. This trend is associated with several negative sequelae, such as a decrease in early hospice enrollment [28] [29] [30] and increased emergency room visits, hospitalizations, and ICU admissions in the last months of life [31]. Receipt of palliative chemotherapy in 
the last month of life is the greatest predictor of intensive end-of-life care [32] [33] [34]. Aggressive end-of-life care is associated with a poorer QOL without an improvement in survival [35] [36] [37]. In 2004, Yun et al. found that $48.7 \%$ of cancer patients received chemotherapy in the last 6 months of life and $30.9 \%$ in the last month [38]. Other studies have confirmed that $20 \%-50 \%$ of patients receive chemotherapy within the last month of life [39] [40]. Among patients receiving chemotherapy in their last month of life, 54\% had already received two to three previous lines of chemotherapy, $25 \%$ received more than three lines and the remaining $21 \%$ only one line of chemotherapy [41]. Estimates of first dose of chemotherapy within the last month of life have been as high as 54\% - 56\% [42] [43] [44].

Table 2 summarizes a review of the use of chemotherapy at the end-of-life for various cancer types. The median duration of responses ranged from 2 months to 12 months with median survivals ranging from 6 months to 3 years [45]. In another institutional review of patients with non-small cell lung cancer, median overall survival was 54 days and ECOG performance status 3 and 4 were most predictive of lack of response to chemotherapy [46]. Age, per se, is not a contraindication to palliative chemotherapy for those patients with a good performance status [47] [48] [49] [50].

Chemotherapy in the last month of life is administered significantly more frequently to patients who are younger, have chemo-responsive disease or who ultimately die at a relatively small hospital without a hospice inpatient unit [38] [51]. Access to palliative services may affect treatment decisions. Fifty-two percent of patients living in areas without palliative care services received chemotherapy in the last three months compared to $27 \%$ of those with palliative care in their community, suggesting that access to palliative care services may make a difference in who is receiving more aggressive treatment [41]. Second- and third-line chemotherapy typically is less likely to impact cancer regression and is

Table 2. Response and survival data [45].

\begin{tabular}{cccc}
\hline Cancer Type & $\begin{array}{c}\text { Response } \\
\text { Rate }\end{array}$ & $\begin{array}{c}\text { Median Duration } \\
\text { of response } \\
\text { (months) }\end{array}$ & $\begin{array}{c}\text { Median } \\
\text { Survival } \\
\text { (months) }\end{array}$ \\
\hline Breast & $25 \%-55 \%$ & $6-12$ & $24-36$ \\
Colon & $25 \%-55 \%$ & $6-8$ & $12-18$ \\
Lung-non-small cell & $20 \%-30 \%$ & $4-6$ & $6-9$ \\
Esophagus & $30 \%-50 \%$ & $4-6$ & $6-9$ \\
Stomach & $20 \%-30 \%$ & $4-6$ & $6-9$ \\
Melanoma & $15 \%-25 \%$ & $4-6$ & $6-9$ \\
Pancreas & $15 \%-25 \%$ & $3-5$ & $6-9$ \\
Liver & $5 \%-15 \%$ & $2-4$ & $6-9$ \\
Biliary & $5 \%-15 \%$ & $2-4$ & $6-9$ \\
\hline
\end{tabular}


associated with more severe side effects [52]. This data suggests that the institution of new anti-cancer therapy or continuation of ongoing therapy very near death is inappropriate and does not alleviate suffering [31].

In theory, if chemotherapy near the end-of-life could in fact maintain or improve QOL or significantly extend life then its use would be justified. However, neither has proven true. In fact, treatment with chemotherapy following multiple prior lines in the setting of progression of disease is not indicated. In a retrospective review of 274 patients with platinum resistant or refractory ovarian cancer, with $28 \%$ of women commencing cytotoxic therapy in the last three months of life, treatment efficacy declined rapidly with successive lines of therapy specifically in the setting of disease progression after first line therapy [53]. Median survival statistics for patients achieving a complete or partial response was 118 weeks and 104 weeks for those who achieved stable disease. On the other hand, the median survival of patients whose disease progressed on first line therapy was only 40 weeks. Among women who progressed during previous lines of chemotherapy, overall survival was 49,37 , and 30 weeks at first, secondand third-line treatments. Furthermore, poor efficacy was seen across all lines of therapy after failure to respond to two cycles of therapy [42] [54]. In a study of 100 consecutive patients with unresectable colorectal cancer, individual QOL deteriorated constantly over lines of chemotherapy [55].

Currently, there are no clear recommendations for when cessation of chemotherapy should occur. Concise clinical pathways that determine when additional therapy is investigational only and when it is unlikely to offer further improvement either in QOL or disease-free interval should be developed [56]. Two relapses within six months can be an indicator for stopping treatment and two consecutive progressions predicts the futility of further anticancer therapy [57]. Griffiths et al. conclude that patients with ovarian cancer who progress without response to two prior lines of chemotherapy, should discontinue cytotoxics [53]. Patients receiving futile therapy are ultimately being administered a toxic and potentially life-threatening treatment that may result in substantial worsening of QOL. Patients who refused further chemotherapy and those who were refractory to chemotherapy showed similar survivals [58].

\section{Importance of Prognosis}

Prognosis is the single most important factor for consideration among patients and providers when determining the next step for treatment. Patients' preferences will differ based on their clinical condition and prognosis [59] [60]. A realistic understanding of prognosis and the goals of cancer therapy will help inform treatment decisions for patients receiving chemotherapy with short life expectancies [61] [62]. Studies show that patients with incurable disease want truthful information about their diagnosis, treatment options and course even if the outlook is poor [42]. Smith found that $100 \%$ of patients wanted to know all the available information and there was no change in hope or distress noted 
when information was given [63]. Patients place greater value on receiving straight talk as well as compassion from their physician [64] and discussion about prognosis correlated with better QOL [38] [65].

In the world of oncology, prognosis is a fluid notion that is based on the performance status of the patient, their initial response to treatment, progression-free survival since the previous line of therapy, and the development of potentially promising new therapies [66]. Honest discussions about poor prognosis are difficult and made more complex when attempting to incorporate all these elements. The inability to relay unfavorable prognostic information relates in part to inherent prognostic uncertainty [67]. Estimating and explaining typical, best case and worse case scenarios for survival is preferable to presenting a single-point estimate of the median survival and can help the clinician convey realistic hope [68]. Table 3 summarizes one tool used for prognostication uses percentages of survival in best case to worse case scenarios based on percentile [68].

The use of these equations accurately estimated selected percentiles for most survival curves greater than $90 \%$ of the time, except for worst-case scenario where accurate estimates occurred in only $73 \%$ of survival curves. Other prognostic scoring using comorbidities and nutritional status can be helpful [69]. A systematic review to evaluate patients' awareness of prognosis revealed that patients who were aware of their disease status were significantly less likely to choose life-extending treatment measures [70].

\section{Barriers for Patients}

Important barriers that the patient faces concerning the decision to cease chemotherapy include misinformation, misinterpretation of information, and concern for loved ones [32] [71]. When patients aren't given full disclosure about their disease or prognosis, they are unable to make informed decisions. With accurate data about disease process and prognosis, patients with terminal illness are less likely to choose aggressive treatment. In one study, a decision aid in a randomized controlled trial of 386 women gave them access to their prognosis and treatment effect. After the intervention only $58 \%$ of women in the decision aid group chose adjuvant chemotherapy, whereas $87 \%$ of their counterparts chose it [72]. Patient reported outcomes can be another decision aid for palliative chemotherapy [73].

Table 3. Use of percentages of survival for prognostication.

\begin{tabular}{cc}
\hline Scenarios & Percentile of Survival \\
\hline Best Case Scenario & median survival $\times 3(90$ th percentile $)$ \\
Upper-Typical & median survival $\times 2(75$ th percentile $)$ \\
Average & median survival $(50$ th percentile $)$ \\
Lower-Typical & median survival $\times 0.5(25$ th percentile $)$ \\
Worst Case Scenario & median survival $\times 0.25(10$ th percentile $)$
\end{tabular}


Table 4 summarizes patient barriers to stopping cytotoxic therapies. QOL considerations can also help guide a patient's decision making towards or against more chemotherapy [74]. In the prospective HOLISTIC study, a multinational, prospective assessment of health-related QOL, patients with soft tissue sarcomas, were asked about attitudes toward length of life versus QOL [75]. Younger patients prioritized length of life over QOL but attitudes shifted with age and performance status.

Patients with advanced cancer can misinterpret accurate information about their diagnosis and retain inaccurate perceptions of their illness [61]. Patients can mistake palliative chemotherapy for curative, even after information is given, and nearly all overestimate the effect of palliative chemotherapy. Cancer patients who overestimate their survival are more likely to die a "bad" death, defined as in an intensive care unit (ICU), on a ventilator, or multiple Emergency Department visits or hospitalizations without achieving life extension [43] [76]. Inaccurate perceptions may also lead to poorer decision making. Patients with advanced cancer who have a poor understanding of their disease often overestimate their prognosis and are more likely to choose aggressive and costly medical care at the end-of-life [77].

In contrast, patients who are aware of their terminal status are more likely to use palliative care and less likely to use aggressive measures, including admission to the ICU [38]. One resource to overcome poor decision making near end-of-life is to integrate palliative care earlier in treatment [33] [78]. Temel performed a

Table 4. Patient barriers to stopping chemotherapy.

\begin{tabular}{|c|c|}
\hline BARRIERS & COMMENTS \\
\hline Denial & $\begin{array}{l}\text { - Unrealistic expectations } \\
\text { - Family denial }\end{array}$ \\
\hline Fear & $\begin{array}{l}\text { - Concern of physician abandonment } \\
\text { - Concern about "giving up" }\end{array}$ \\
\hline Sense of duty & Family demands and wishes \\
\hline Anger & $\begin{array}{c}\text { Questioning whether the disease course could } \\
\text { have been altered with an earlier diagnosis or } \\
\text { different treatment choice }\end{array}$ \\
\hline Hope & Belief in a miracle \\
\hline Health literacy & $\begin{array}{l}\text { - } \text { Misunderstanding palliative care } \\
\text { - Communication barriers } \\
\text { - Language barriers }\end{array}$ \\
\hline \multicolumn{2}{|l|}{ Young age of patient } \\
\hline \multicolumn{2}{|l|}{ Religious background } \\
\hline Cultural background & 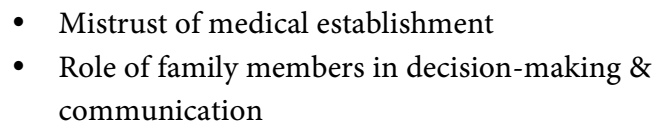 \\
\hline
\end{tabular}


randomized controlled trial of early palliative care integrated with standard oncology care versus standard care alone and found that a greater percentage of patients in the early palliative care arm retained or developed an accurate assessment of their prognosis over time (82.5\% vs $59.6 \%)$. She also found a significant improvement in QOL, mood as well as survival, among those who received early palliative care [61]. Framing palliative care as an extra layer of support that can be given alongside curative treatment may make patients more likely to accept it [79]. For some patients, families are reluctant to stop therapy even when the patient wants to. In a study of 167 patients with advanced genitourinary cancer who decided to stop their cancer treatment, the median survival period was six times longer (145.5 days) than when the family made the decision to stop (23 days) [80]. This suggests the importance of supporting and educating families during these difficult times. Another study identified a direct correlation of patient Do Not Resuscitate (DNR) order status and the families' understanding of prognosis [71].

Physicians may underestimate the strong influence they have on their patients, via explicit and implicit remarks. Patients may be frightened by the fact that they could decide their treatment for themselves [81]. An oncologist who describes an anecdotal success for a therapy may easily encourage a patient, against that patient's own preferences, to continue treatment [82].

Another barrier for patients is the assumption that ceasing chemotherapy is the equivalent of giving up hope. They do not want to feel as if they are waiting to die [83]. Any sort of active treatment plan, no matter how small or large, therapeutic, or harmful, will seem better than "doing nothing" [84]. Patients with cancer are generally willing to face the prospect of major adverse events in exchange for small therapeutic benefits more frequently than well people and healthcare professionals [85]. There is an impulse to do any and everything possible to extend life. This attitude may be magnified among patients' family members (et al., 2021). Patients do not want to disappoint their families, for such an action can be extremely psychologically distressing [86]. Concern for family and friends has a negative impact on QOL [87]. This too is another barrier that these patients are faced with.

Belief in miracles may impact medical decision making as well [88]. Sixty-four percent of interviewed surrogates of critically ill patients expressed reluctance or unwillingness to believe their physicians' futility predictions and would prefer to continue exhausting treatment options [89]. Reasons include skepticism about provider's prognostic abilities, a need to see for themselves that a patient was incapable of recovery, a need to triangulate multiple sources of information, and a belief that God could intervene to change the course of a hopeless situation. Seventy-nine percent of 35,556 respondents agreed that miracles still occur [90]. Fifty-seven percent believed that divine intervention from God could save a person if a physician told them that "futility had been reached" [91].

Patients fear pain, losing control, becoming totally dependent, or dying [92]. Fear is the most dominant psychosocial consequence of having cancer. On other 
hand, for some people, avoiding therapy, particularly when it is seen as a last resort, allows them to take control over their lives and achieve a better QOL in their remaining months or years [93].

\section{Barriers for Providers}

Barriers that providers face surrounding chemotherapy cessation include fear of giving up too soon, poor prognostication, acceptance of a failure of medicine, fear of losing a patient, lack of experience and difficulty sharing bad news [94] [95]. When the time approaches that chemotherapy is no longer effective, there needs to be a balance of being truthful while simultaneously protecting hope. Table 5 summarizes barriers that physicians and healthcare providers face to their decision making to stop chemotherapy.

Commonly, providers do not provide information purposefully to avoid emotional distress and may choose not to be fully honest to preserve hope [96]. Physicians fear being the destroyer of hope and struggle with being seen as the bearer of bad news [97]. According to Smith however, hope is typically maintained even in the gloomiest of circumstances. In an advanced cancer population, patients who were given a poor prognosis, low likelihood of response to therapy and no chance of cure remained hopeful about their futures [63]. Furthermore, The Coping with Cancer study showed that patients who reported having end-of-life discussions with their providers had no higher rates of depression or worry than those who did not discuss end-of-life with their providers [30] [98].

Also, providers do not want to give the impression of defeat to their patients. Shifting goals of care may ultimately feel like a failure of medicine. It is easier for a physician to recommend another line of chemotherapy than to discuss shifting

Table 5. Physician barriers to stopping chemotherapy.

\begin{tabular}{cll}
\hline \multicolumn{1}{c}{ BARRIERS } & \multicolumn{1}{c}{ COMMENT } \\
\hline Poor estimation and prognostication & & \\
\hline Difficulty delivering difficult news & - & Fear of harm \\
& Fear of disappointing \\
\hline Fear of patient or family anger & & \\
\hline Clinical trials push & - & Pressure to enroll patients on trials \\
& Academic incentives \\
\hline Lack of training in palliative care & & \\
\hline Fragmentation of healthcare & - & Lack of multidisciplinary cancer care team \\
& Lack of resources - rural environment \\
\hline Institutional culture & Legal resources in the setting of medical \\
& futility \\
& Ethics committee support
\end{tabular}


goals of therapy [31]. Though the reasons for prescribing chemotherapy in patients with poorly responsive cancers are not based on scientific evidence [96], patients eagerly follow physicians' offers of treatment, falsely interpreting it as a sign of hope [77] [99]. However, considering minimal hope, continuing chemotherapy may prevent patients from preparing themselves for death [43] [62]. Use of chemotherapy at the end-of-life is not related to its likelihood of providing benefit [100] [101]. The only predictive factor for chemotherapy use in the last month of life is the individual clinician.

Whether out of prognostic uncertainty or discomfort for having difficult conversations, oncologists may also feel they are being kind by deferring the ultimate decision about chemotherapy cessation. Instead, physician strategies may include waiting to see if the patient "gets stronger." Even with new modalities of immunotherapy and targeted therapies for patients at the end-of-life, Yeh and colleagues found that of oncology patients who were discharged to subacute rehabilitation units, two-thirds never received additional cancer therapy. A substantial fraction was either re-hospitalized or died within one month [102]. The decline in referrals from inpatient oncology to hospice and increased placements in subacute rehabilitation units seem to represent missed opportunities to explore and honor patients' goals and values for a hope that materializes in only a minority of cases.

Physicians fear that they will be perceived as giving up if they talk about dying, thereby eliminating hope and depressing patients [103]. Most patients never receive information from their physicians about prognosis or even imminent death [104] [105]. Even when terminally ill patients with cancer request survival estimates, doctors provide such estimates about $37 \%$ of the time and consistently and consciously overestimate prognosis by at least 30\%. Additionally, prognostication worsened the longer physicians had known their patients and the more recently they had seen them [106]. In fact, prediction of life expectancy is accurate in only $30 \%-40 \%$ of cases [94]. Physicians give the least honest figures to those with the worst prognosis [26]. Most oncologists find breaking bad news to be stressful, and few find it satisfying [107]. When physicians discuss death with the patient and family, there is significantly improved quality of care, QOL for the patient and QOL for the caregiver [27] [83]. It is important to keep in mind that though at times sharing the entire truth is difficult, honest information respects patient autonomy, allowing them to make more informed decisions [63].

A particularly ethically challenging situation is the patient request for active therapy that the medical team assesses as futile. In some cases, preference for active treatment is a result of patient's denial [108] [109] and this should be addressed. Again, providers fear being the destroyer of hope and will continue treatment against their better judgement. Conversely decisions may be complicated by the oncologists' anecdotal experience of the occasional patient who seemed to respond to late-line chemotherapy [31]. Providers need to feel comfortable communicating their own values and experiences and providing guidance and support in a collaborative manner while expressing interest in and re- 
spect for that of the patient [110]. These conversations must reflect both reasonable standards of good medical practice and goals that medicine can reasonably hope to achieve. Institutional culture can also play a role in physician decision-making at the end-of-life. One qualitative research study identified that paradoxically, too singular a focus on patient autonomy may unintentionally undermine patient care by withholding professional guidance and medical opinion about appropriate medical care [111].

Many medical oncologists agree that they should coordinate end-of-life care. In a 2003 survey, $43 \%$ of respondents did so [112]. There has been a growing consensus on the importance of incorporating palliative care into ongoing oncologic care [84] [113] [114] [115] [116] [117]. Providers may fear of losing a patient after a difficult end-of-life conversation. Burnout among oncologists is associated with low levels of preparedness for emotionally taxing professional activities such as end-of-life discussions [118] [119]. Dealing with and speaking about death regularly is a difficult task [120]. Oncologists may do so more often than other physicians and perhaps have a heightened desire to keep their patients around longer. In fact, patients cared for by oncologists are referred to hospice later than those cared for by other physicians [115] [121] [122]. Continuing chemotherapy may somehow dampen the fear of losing a patient by continuing the active fight. All oncologists highly value patients' QOL but choosing to prescribe further chemotherapy seems to depend more on the importance they attached to prolonging a patient's life [99].

Financial considerations are another element that may play a role in therapy at the end-of-life. There is very little data concerning provider bias based on reimbursement. However, concerning reimbursement in private practice, greater than $50 \%$ of the profit comes from the sale of chemotherapy drugs [123]. Furthermore, the cost of chemotherapy has increased significantly in the past decade. Resources are another factor as well. If high quality palliative care is not available, oncologists tend to continue giving chemotherapy longer than they would otherwise [31] [124]. However, ultimately the utilization of chemotherapy in the final stages of cancer is driven by the physician-patient interaction. Both parties mutually enforce the attitude of not giving up.

\section{Disparities in Oncology Care at the End-of-Life}

As more attention is rightly being paid to the structural racism that exists in healthcare, it is crucial for physicians to examine their unconscious biases that may play a role in determining which patients are offered further treatment at end-of-life and which are not. There have been analyses of disparities in upfront therapy such as surgical interventions leading to differences in survival [125]. Similarly, there are disparities at the end-of-life [126]. Mullins et al. found that Non-White women with ovarian cancer were more likely to receive aggressive end-of-life care and non-Hispanic Black women were more likely to have Emergency Department visits and undergo procedures near end-of-life as compared with non-Hispanic White women [127]. Another study of cancer patients at 
end-of-life found that while a minority of participants received life expectancy information from their physician, none of the Black patients did [128] which may contribute to why Black cancer patients receive more burdensome care at end-of-life than white patients [129]. Penner et al. found that oncologists with higher implicit racial biases had shorter interactions with Black patients that were rated by patients and observers as less supportive and patient-centered [130]. This inequity in communication becomes more striking at end-of-life, where oncologists have been found to spend less time having goals of care discussions with minority patients than with nonminority patients [131]. In addition to addressing these issues at the systemic level through means such as advocating for a more diverse oncology workforce, is crucial that as individual providers, we examine our own implicit biases and strive for equity in when, how, and for whom we are deciding to stop chemotherapy [132].

\section{Other Considerations}

Discussions about stopping chemotherapy should include understanding the relative weight placed by a patient on prolonging life as opposed to enhancing QOL [61] [133] [134] [135]. At some point the limitations of medicine will be confronted, and the reality that life is finite is realized [34] [105]. The cessation of futile therapy is justified, for they burden the patient in the absence of benefit. Futile therapy is defined as contrary to justice because it does not represent a just allocation of resources. Oncologists must be prepared to tell their patient when they'd be better off without another line of treatment, even if this means initiating an end-of-life discussion [31]. This may be framed as discussing burdens and benefits of treatments, ideally as one would do all throughout the disease trajectory, so this framing is familiar to patients. Such end-of-life discussions are associated with less aggressive medical care near death and earlier hospice referral [34]. These discussions are also associated with lower rates of ventilation, resuscitation, or ICU admission, longer hospice stay and better QOL [83]. Only 37\% of patients report having end-of-life discussions with providers. End-of-life discussion should take place in a quiet, comfortable, private location with adequate uninterrupted time [136]. Oncologists may use the frame that at this point in the patient's disease progression, the burdens of a treatment outweigh the benefits, and as such it makes sense to shift focus onto what can be done at end-of-life rather than focusing on what is being taken away. This involves an exploration of a patient's goals and values considering recommendations for aggressive comfort-focused care.

Also, events considered likely to occur given the clinical condition and what may happen with withholding treatment should be discussed [137] [138]. Providers should address potential management of common symptoms, which include nausea, vomiting, opioid induced constipation, nutrition issues, small bowel obstruction, obstructive nephropathy, dyspnea, ascites, hypercalcemia, and delirium [139]. Pain is a very common fear among patients with terminal cancer. As many as $60 \%-90 \%$ of patients with advanced cancer will experience pain 
(Lee et al., 2015) [39], while it can be controlled in about $80 \%$ of patients as many as $50 \%$ of cancer patients with pain may remain untreated [140]. Good symptom management is critical to improving QOL in patients with advanced cancer. The dying cancer patient should never be allowed to live out his or her life with unrelieved pain because of fear of side effects [141]. Palliative care teams can provide expert guidance on symptom control and management of side effects in challenging situations.

The most frequently documented unmet needs at end-of-life were psychological needs [87]. Over half of cancer patients report needing help dealing with emotional problems. Seventy-three percent would prefer for physicians to directly ask whether help is needed [142]. Interventions providing emotional and social support at the end-of-life have a positive influence on the physiological stress-response systems that affect survival. These interventions also improve QOL [143] [144].

Early palliative care is something that should be considered as well [79]. As mentioned above, Temel compared outcomes for patients who received early palliative care with standard oncology care versus standard oncology care alone. Even though fewer patients in the early palliative care group received aggressive end of life care (33\% versus 54\%) median survival was longer among patients receiving early palliative care (11.6 months versus 8.9 months) [61]. Delays in referral to palliative care services causes difficult integration between primary anticancer care and supportive/palliative care [134]. Learning that patients who received early palliative care had prolonged survival may be reassuring to patients and providers of health care [145]. Patient's receiving early palliative care also have half the odds of receiving chemotherapy within 60 days of death, longer interval between last dose of intravenous chemotherapy and death, and higher enrollment in hospice care for longer than one week [146]. The literature not only suggests that patients receiving palliative care may live longer, but their QOL is also improved [147] [148]. Patients spend less of their time at the end-of-life in hospital or focused on medical treatments. Additionally, chemotherapy administration near time of death may delay or prevent access to hospice services, because hospice agencies in the United States often lack funds to pay for chemotherapy or recurrent hospital stays [34]. Of note, half of bereaved family members felt that timing of referrals to palliative care for their loved ones was too late [149].

Lastly, physicians must remember to address patients' spiritual needs as well. Spirituality and religiosity are well recognized as factors that affect patient QOL, quality of care, and satisfaction. Most patients report that these two items help them cope with their cancer and prognosis as well as serve as a source of strength and comfort [150]. The Coping with Cancer study showed that $60 \%$ of patients reported their spiritual needs were minimally or not at all supported by the medical system and those whose needs were met had threefold greater odds of receiving hospice care and less likely to receive aggressive care [98]. Studies have suggested that greater attention to spiritual beliefs can foster a negotiated 
and mutually acceptable plan of care [151].

\section{Best Practices for Having the Conversation about Stopping Chemotherapy}

1) Early in the disease course, introduce the concept that chemotherapy has burdens and benefits which must be weighed against one another, so patients become familiar with this framing, forecasting that there may come a point when the burdens outweigh the benefits.

2) Acknowledge the implicit biases that each of us have and examine how these might impact the choices providers make about goals of care conversations with patients.

3) Consider having goals of care conversations earlier than you normally would, acknowledging that most physicians overestimate prognosis, particularly for patients at end-of-life and those they have known the longest [106].

4) Consider using a structured framework for goals of care conversations in advanced oncology patients such as REMAP [152]. See Table 6 for sample language.

Table 6. Example conversation regarding discontinuing chemotherapy using the REMAP framework [152] [153].

\begin{tabular}{|c|c|c|}
\hline & Step & Sample Language \\
\hline $\mathrm{R}$ & $\begin{array}{l}\text { 1) Reframe why the } \\
\text { current plan isn't } \\
\text { working }\end{array}$ & $\begin{array}{l}\text { (This may require breaking bad news of disease } \\
\text { progression first). } \\
\text { "Given the new tumors we saw on your scan, } \\
\text { I'd like to talk about next steps. Would that be ok?" }\end{array}$ \\
\hline $\mathrm{E}$ & $\begin{array}{l}\text { 2) Expect emotion. } \\
\text { Empathize with the } \\
\text { patient }\end{array}$ & $\begin{array}{l}\text { "It sounds like you're feeling really shocked." } \\
\text { "I can tell this isn't what you were expecting to hear." } \\
\text { "I can imagine how overwhelming this is." }\end{array}$ \\
\hline M & 3) Map the future & $\begin{array}{l}\text { "When you think about the future, are there things } \\
\text { you're worried about? Things you're hoping for?" } \\
\text { "Given that time may be short, what's most } \\
\text { important to you now?" }\end{array}$ \\
\hline A & $\begin{array}{l}\text { 4) Align with the } \\
\text { patient's values }\end{array}$ & $\begin{array}{l}\text { "It sounds like the most important things are getting } \\
\text { your pain under control and having good time at } \\
\text { home with your children and dog." } \\
\text { "What I'm hearing you say is that the time you've } \\
\text { been spending in the hospital has been really difficult, } \\
\text { and if we could get your pain under control you'd } \\
\text { prefer to stay at home." }\end{array}$ \\
\hline $\mathrm{P}$ & $\begin{array}{l}\text { 5) Propose a plan that } \\
\text { matches patient values }\end{array}$ & $\begin{array}{l}\text { "Given what you've said, I propose that we start some } \\
\text { medications to help get your pain under control so } \\
\text { you can get home and spend good time with your } \\
\text { family. I don't think more chemotherapy is going to } \\
\text { help you stay home or be comfortable. I think getting } \\
\text { hospice on board would help with managing the pain } \\
\text { while allowing you to stay home. What do you think?" }\end{array}$ \\
\hline
\end{tabular}


5) Expect that these conversations may be iterative. Patients may ask again about chemotherapy and framing in terms of the burdens outweighing the benefits may be useful.

6) Consider consulting palliative care teams even before having these conversations (integrated with usual oncology care).

7) When introducing palliative care or hospice, frame them in terms of what services may be provided or symptoms addressed, rather than in terms of taking things away or because "there's nothing left to offer." Instead: "It sounds like pain has been a challenge and coming into the clinic for me to assess it takes up a lot of your energy. One thing that may help is having a team that comes to your house to help with medications instead. The way that I can arrange for that is through hospice, since they can provide that service as well as others [153].

8) Understand that these conversations are challenging for all physicians. However, knowledge of communication frameworks and feeling comfortable breaking bad news may be protective against burnout [154].

\section{Conclusion}

It is imperative that cancer care providers appreciate the profound anxiety experienced at the junction between life and death. Currently, patients and their families are most in need of honesty, kindness, and engagement [147] [148]. The decision to cease chemotherapy is one that should be approached with careful consideration and accurate information. It is perhaps the most significant, empowering, and terrifying turning point in a patient's journey. An honest, intimate, and collaborative patient-physician relationship is key during this time. For when all barriers are acknowledged and overcome, personal connections between the patient and the healthcare will determine the solution to the question "what next?".

\section{Conflicts of Interest}

The authors declare no conflicts of interest regarding the publication of this paper.

\section{References}

[1] Archer, V.R., Billingham, L.J. and Cullen, M.H. (1999) Palliative Chemotherapy: No Longer a Contradiction in Terms. Oncologist, 4, 470-477.

https://doi.org/10.1634/theoncologist.4-6-470

[2] Chan, W.L., Yuen, K.K., Siu, S.W., Lam, K.O. and Kwong, D.L. (2017) Third-Line Systemic Treatment versus Best Supportive Care for Advanced/Metastatic Gastric Cancer: A Systematic Review and Meta-Analysis. Critical Reviews in Oncology/Hematology, 116, 68-81. https://doi.org/10.1016/j.critrevonc.2017.05.002

[3] Crosara Teixeira, M., Marques, D.F., Ferrari, A.C., Alves, M.F., Alex, A.K., Sabbaga, J., Hoff, P.M. and Riechelmann, R.P. (2015) The Effects of Palliative Chemotherapy in Metastatic Colorectal Cancer Patients with an ECOG Performance Status of 3 and 4. Clinical Colorectal Cancer, 14, 52-57.

https://doi.org/10.1016/j.clcc.2014.09.010 
[4] Kim, J.W., Kim, J.G., Kang, B.W., Chung, I.J., Hong, Y.S., Kim, T.Y., Song, H.S., Lee, K.H., Zang, D.Y., Ko, Y.H., Song, E.K., Baek, J.H., Koo, D.H., Oh, S.Y., Cho, H. and Lee, K.W. (2019) Treatment Patterns and Changes in Quality of Life during First-Line Palliative Chemotherapy in Korean Patients with Advanced Gastric Cancer. Cancer Research and Treatment, 51, 223-239.

https://doi.org/10.4143/crt.2018.073

[5] Penson, R.T., Wenzel, L.B., Vergote, I. and Cella, D. (2006) Quality of Life Considerations in Gynecologic Cancer. FIGO 26th Annual Report on the Results of Treatment in Gynecological Cancer. International Journal of Gynecology \& Obstetrics, 95, S247-S257. https://doi.org/10.1016/S0020-7292(06)60040-4

[6] Carey, M.S., Bacon, M., Tu, D., Butler, L., Bezjak, A. and Stuart, G.C. (2008) The Prognostic Effects of Performance Status and Quality of Life Scores on Progression-Free Survival and Overall Survival in Advanced Ovarian Cancer. Gynecologic Oncology, 108, 100-105. https://doi.org/10.1016/j.ygyno.2007.08.088

[7] Tsuboi, R., Sugishita, M., Hirakawa, Y. and Ando, Y. (2020) Experiences and Hidden Needs of Older Patients, Their Families and Their Physicians in Palliative Chemotherapy Decision-Making: A Qualitative Study. Japanese Journal of Clinical Oncology, 50, 779-786. https://doi.org/10.1093/jjco/hyaa020

[8] Dignan, F., Seiden, M.V., Lee, H., Gallagher, C.J., Matulonis, U.A., Olson, K., Gibbens, I. and Gore, M.E. (2004) Attitudes to Chemotherapy in Patients with Ovarian Cancer. Gynecologic Oncology, 94, 427-435. https://doi.org/10.1016/j.ygyno.2004.05.034

[9] Jansen, L., Hoffmeister, M., Chang-Claude, J., Koch, M., Brenner, H. and Arndt, V. (2011) Age-Specific Administration of Chemotherapy and Long-Term Quality of Life in Stage II and III Colorectal Cancer Patients: A Population-Based Prospective Cohort. Oncologist, 16, 1741-1751. https://doi.org/10.1634/theoncologist.2011-0124

[10] Jansen, K., Haugen, D.F., Pont, L. and Ruths, S. (2018) Safety and Effectiveness of Palliative Drug Treatment in the Last Days of Life-A Systematic Literature Review. Journal of Pain and Symptom Management, 55, 508-521.E3. https://doi.org/10.1016/j.jpainsymman.2017.06.010

[11] von Gruenigen, V.E., Huang, H.Q., Gil, K.M., Frasure, H.E., Armstrong, D.K. and Wenzel, L.B. (2012) The Association between Quality of Life Domains and Overall Survival in Ovarian Cancer Patients during Adjuvant Chemotherapy: A Gynecologic Oncology Group Study. Gynecologic Oncology, 124, 379-382.

https://doi.org/10.1016/j.ygyno.2011.11.032

[12] Morton, L.M., Dores, G.M., Schonfeld, S.J., Linet, M.S., Sigel, B.S., Lam, C.J., Curtis, R.E., et al. (2019) Association of Chemotherapy for Solid Tumors with Development of Therapy-Related Myelodysplastic Syndrome or Acute Myeloid Leukemia in the Modern Era. JAMA Oncology, 5, 318-325.

https://doi.org/10.1001/jamaoncol.2018.5625

[13] Tschernichovsky, R., Philp, L. and Goodman, A. (2019) Chemotherapy-Induced Cognitive Decline: Moving from the Mechanistic Debate towards Prevention and Treatment-A Clinical Review. Journal of Cancer Therapy, 10, 985-1012. https://doi.org/10.4236/jct.2019.1012084

[14] Park, S.B., Krishnan, A.V., Lin, C.S., Goldstein, D., Friedlander, M. and Kiernan, M.C. (2008) Mechanisms Underlying Chemotherapy-Induced Neurotoxicity and the Potential for Neuroprotective Strategies. Current Medicinal Chemistry, 15, 3081-3094. https://doi.org/10.2174/092986708786848569

[15] Young, K. and Singh, G. (2018) Biological Mechanisms of Cancer-Induced Depression. Frontiers in Psychiatry, 9, Article No. 299. 
https://doi.org/10.3389/fpsyt.2018.00299

[16] Fabbrocini, G., Cameli, N., Romano, M.C., Mariano, M., Panariello, L., Bianca, D. and Monfrecola, G. (2012) Chemotherapy and Skin Reactions. Journal of Experimental \& Clinical Cancer Research: CR, 31, Article No. 50.

https://doi.org/10.1186/1756-9966-31-50

[17] Bhalla, K.S., Wilczynski, S.W., Abushamaa, A.M., Petros, W.P., McDonald, C.S., Loftis, J.S., Chao, N.J., Vredenburgh, J.J. and Folz, R.J. (2000) Pulmonary Toxicity of Induction Chemotherapy Prior to Standard or High-Dose Chemotherapy with Autologous Hematopoietic Support. American Journal of Respiratory and Critical Care Medicine, 161, 17-25. https://doi.org/10.1164/ajrccm.161.1.9903059

[18] Florescu, M., Cinteza, M. and Vinereanu, D. (2013) Chemotherapy-Induced Cardiotoxicity. Maedica, 8, 59-67.

[19] Forsgård, R.A., Marrachelli, V.G., Korpela, K., Frias, R., Collado, M.C., Korpela, R., Monleon, D., Spillmann, T. and Österlund, P. (2017) Chemotherapy-Induced Gastrointestinal Toxicity Is Associated with Changes in Serum and Urine Metabolome and Fecal Microbiota in Male Sprague-Dawley Rats. Cancer Chemotherapy and Pharmacology, 80, 317-332. https://doi.org/10.1007/s00280-017-3364-Z

[20] Wong, T.M., Yeo, W., Chan, L.W. and Mok, T.S. (2000) Hemorrhagic Pyelitis, Ureteritis, and Cystitis Secondary to Cyclophosphamide: Case Report and Review of the Literature. Gynecologic Oncology, 76, 223-225.

https://doi.org/10.1006/gyno.1999.5680

[21] Wang, Y., Probin, V. and Zhou, D. (2006) Cancer Therapy-Induced Residual Bone Marrow Injury-Mechanisms of Induction and Implication for Therapy. Current Cancer Therapy Reviews, 2, 271-279. https://doi.org/10.2174/157339406777934717

[22] Mangan, B.L., McAlister, R.K., Balko, J.M., Johnson, D.B., Moslehi, J.J., Gibson, A. and Phillips, E.J. (2020) Evolving Insights into the Mechanisms of Toxicity Associated with Immune Checkpoint Inhibitor Therapy. British Journal of Clinical Pharmacology, 86, 1778-1789. https://doi.org/10.1111/bcp.14433

[23] Gough, N., Koffman, J., Ross, J.R., Riley, J. and Judson, I. (2019) Does Palliative Chemotherapy Really Palliate and Are We Measuring It Correctly? A Mixed Methods Longitudinal Study of Health-Related Quality of Life in Advanced Soft Tissue Sarcoma. PLoS ONE, 14, e0210731. https://doi.org/10.1371/journal.pone.0210731

[24] Markman, M. (2006) Palliative Chemotherapy "Near the End-of-Life" in Ovarian Cancer: Not Necessarily "Aggressive Cure-Oriented Therapy”. Gynecologic Oncology, 101, 198-199. https://doi.org/10.1016/j.ygyno.2006.01.008

[25] Fiorin de Vasconcellos, V., Rcc Bonadio, R., Avanço, G., Negrão, M.V. and Pimenta and Riechelmann, R. (2019) Inpatient Palliative Chemotherapy Is Associated with High Mortality and Aggressive End-of-Life Care in Patients with Advanced Solid Tumors and Poor Performance Status. BMC Palliative Care, 18, Article No. 42. https://doi.org/10.1186/s12904-019-0427-4

[26] Lee, M.W., Ryu, H., Song, I.C., Yun, H.J., Jo, D., Ko, Y.B. and Lee, H.J. (2020) Efficacy of Cisplatin Combined with Topotecan in Patients with Advanced Or Recurrent Ovarian Cancer as Second- or Higher-Line Palliative Chemotherapy. Medicine (Baltimore), 99, e19931. https://doi.org/10.1097/MD.0000000000019931

[27] Zhang, B., Nilsson, M.E. and Prigerson, H.G. (2012) Factors Important to Patients' Quality of Life at the End of Life. Archives of Internal Medicine, 172, 1133-1142. https://doi.org/10.1001/archinternmed.2012.2364

[28] Sheffield, K.M., Boyd, C.A., Benarroch-Gampel, J., Kuo, Y.F., Cooksley, C.D. and 
Riall, T.S. (2011) End-of-Life Care in Medicare Beneficiaries Dying with Pancreatic Cancer. Cancer, 117, 5003-5012. https://doi.org/10.1002/cncr.26115

[29] Verhoef, M.J., de Nijs, E.J.M., Ootjers, C.S., Fiocco, M., Fogteloo, A.J., Heringhaus, C., Marijnen, C.A.M., Horeweg, N. and der Linden, Y.M.V. (2020) End-of-Life Trajectories of Patients with Hematological Malignancies and Patients with Advanced Solid Tumors Visiting the Emergency Department: The Need for a Proactive Integrated Care Approach. American Journal of Hospice and Palliative Care, 37, 692-700. https://doi.org/10.1177/1049909119896533

[30] Wright, A.A., Zhang, B., Ray, A., Mack, J.W., Trice, E., Balboni, T., Mitchell, S.L., Jackson, V.A., Block, S.D., Maciejewski, P.K. and Prigerson, H.G. (2008) Associations between End-of-Life Discussions, Patient Mental Health, Medical Care near Death, and Caregiver Bereavement Adjustment. JAMA, 300, 1665-1673.

https://doi.org/10.1001/jama.300.14.1665

[31] Earle, C.C., Neville, B.A., Landrum, M.B., Ayanian, J.Z., Block, S.D. and Weeks, J.C. (2004) Trends in the Aggressiveness of Cancer Care near the End of Life. Journal of Clinical Oncology, 22, 315-321. https://doi.org/10.1200/JCO.2004.08.136

[32] Deeb, S., Chino, F.L., Diamond, L.C., Tao, A., Aragones, A., Shahrokni, A., Yerramilli, D., Gillespie, E.F. and Tsai, C.J. (2021) Disparities in Care Management during Terminal Hospitalization among Adults with Metastatic Cancer from 2010 to 2017. JAMA Network Open, 4, e2125328. https://doi.org/10.1001/jamanetworkopen.2021.25328

[33] Tay, R.Y., Choo, R.W.K., Ong, W.Y. and Hum, A.Y.M. (2021) Predictors of the Final Place of Care of Patients with Advanced Cancer Receiving Integrated HomeBased Palliative Care: A Retrospective Cohort Study. BMC Palliative Care, 20, Article No. 164. https://doi.org/10.1186/s12904-021-00865-5

[34] Wright, A.A., Zhang, B., Keating, N.L., Weeks, J.C. and Prigerson, H.G. (2014) Associations between Palliative Chemotherapy and Adult Cancer Patients' End of Life Care and Place of Death: Prospective Cohort Study. BMJ, 348, g1219.

https://doi.org/10.1136/bmj.g1219

[35] von Gruenigen, V., Daly, B., Gibbons, H., Hutchins, J. and Green, A. (2008) Indicators of Survival Duration in Ovarian Cancer and Implications for Aggressiveness of Care. Cancer, 112, 2221-2227. https://doi.org/10.1002/cncr.23391

[36] von Gruenigen, V.E., Huang, H.Q., Beumer, J.H., Lankes, H., Tew, W., Herzog, T., Hurria, A., Mannel, R.S., Rizack, T., Landrum, L.M., Rose, P.G., Salani, R., Bradley, W.H., Rutherford, T.J., Higgins, R.V., Secord, A.A. and Fleming, G. (2017) Chemotherapy Completion in Elderly Women with Ovarian, Primary Peritoneal or Fallopian Tube Cancer-An NRG Oncology/Gynecologic Oncology Group Study. Gynecologic Oncology, 144, 459-467. https://doi.org/10.1016/j.ygyno.2016.11.033

[37] Saito, A.M., Landrum, M.B., Neville, B.A., et al. (2011) The Effect on Survival of Continuing Chemotherapy to Near Death. BMC Palliative Care, 10, Article No. 14. https://doi.org/10.1186/1472-684X-10-14

[38] Yun, Y.H., Kwak, M., Park, S.M., Kim, S., Choi, J.S., Lim, H.Y., Lee, C.G., Choi, Y.S., Hong, Y.S., Kim, S.Y. and Heo, D.S. (2007) Chemotherapy Use and Associated Factors among Cancer Patients near the End of Life. Oncology, 72, 164-171. https://doi.org/10.1159/000112802

[39] Lee, Y.P., Wu, C.H., Chiu, T.Y., Chen, C.Y., Morita, T., Hung, S.H., Huang, S.B., Kuo, C.S. and Tsai, J.S. (2015) The Relationship between Pain Management and Psychospiritual Distress in Patients with Advanced Cancer Following Admission to a Palliative Care Unit. BMC Palliative Care, 14, Article No. 69. https://doi.org/10.1186/s12904-015-0067-2 
[40] Yoshida, Y. (2019) Current Treatment of Older Patients with Recurrent Gynecologic Cancer. Current Opinion in Obstetrics and Gynecology, 31, 340-344. https://doi.org/10.1097/GCO.0000000000000543

[41] Andreis, F., Rizzi, A., Rota, L., Meriggi, F., Mazzocchi, M. and Zaniboni, A. (2011) Chemotherapy Use at the End of Life. A Retrospective Single Centre Experience Analysis. Tumori, 97, 30-34. https://doi.org/10.1177/030089161109700106

[42] Harrington, S.E. and Smith, T.J. (2008) The Role of Chemotherapy at the End of Life: “When Is Enough, Enough?” JAMA, 299, 2667-2678. https://doi.org/10.1001/jama.299.22.2667

[43] Braga, S. (2011) Why Do Our Patients Get Chemotherapy until the End of Life? Annals of Oncology, 22, 2345-2348. https://doi.org/10.1093/annonc/mdr416

[44] Näppä, U., Lindqvist, O., Rasmussen, B.H. and Axelsson, B. (2011) Palliative Chemotherapy during the Last Month of Life. Annals of Oncology, 22, 2375-2380. https://doi.org/10.1093/annonc/mdq778

[45] Weisman, D.E. and von Gunten, C.F. (2003) Fast Fact and Concept \#099: Chemotherapy: Response and Survival Data. From Fast Facts Index. https://www.mywhatever.com/cifwriter/library/eperc/fastfact/ff99.html

[46] Baldotto, C.S., Cronemberger, E.H., de Biasi, P., Zamboni, M., Sousa, A., Zukin, M. Small, I.A. and Ferreira, C.G. (2012) Palliative Care in Poor-Performance Status Small Cell Lung Cancer Patients: Is There a Mandatory Role for Chemotherapy? Supportive Care in Cancer, 20, 2721-2727. https://doi.org/10.1007/s00520-012-1392-0

[47] Berger, A.K., Zschaebitz, S., Komander, C., Jäger, D. and Haag, G.M. (2015) Palliative Chemotherapy for Gastroesophageal Cancer in Old and Very Old Patients: A Retrospective Cohort Study at the National Center for Tumor Diseases, Heidelberg. World Journal of Gastroenterology, 21, 4911-4918. https://doi.org/10.3748/wjg.v21.i16.4911

[48] Lichtman, S.M. (2014) How I Treat Ovarian Cancer in Older Women. Journal of Geriatric Oncology, 5, 223-229. https://doi.org/10.1016/j.jgo.2014.06.001

[49] Li, Q., Lin, Y., Qiu, Y., Gao, B. and Xu, Y. (2014) The Assessment of Health-Related Quality of Life and Related Factors in Chinese Elderly Patients Undergoing Chemotherapy for Advanced Cancer: A Cross-Sectional Study. The European Journal of Oncology Nursing, 18, 425-435. https://doi.org/10.1016/j.ejon.2014.03.005

[50] Tew, W.P. (2016) Ovarian Cancer in the Older Woman. Journal of Geriatric Oncology, 7, 354-361. https://doi.org/10.1016/j.jgo.2016.07.008

[51] Kao, S., Shafiq, J., Vardy, J. and Adams, D. (2009) Use of Chemotherapy at End of Life in Oncology Patients. Annals of Oncology, 20, 1555-1559.

https://doi.org/10.1093/annonc/mdp027

[52] Prigerson, H.G., Bao, Y., Shah, M.A., et al. (2015) Chemotherapy Use, Performance Status, and Quality of Life at the End of Life. JAMA Oncology, 1, 778-784. https://doi.org/10.1001/jamaoncol.2015.2378

[53] Griffiths, R.W., Zee, Y.K., Evans, S., Mitchell, C.L., Kumaran, G.C., Welch, R.S., Hasan, J., et al. (2011) Outcomes after Multiple Lines of Chemotherapy for Platinum-Resistant Epithelial Cancers of the Ovary, Peritoneum, and Fallopian Tube. International Journal of Gynecologic Cancer, 21, 58-65. https://doi.org/10.1097/IGC.0b013e3182049273

[54] Pujade-Lauraine, E., Hilpert, F., Weber, B., Reuss, A., Poveda, A., Kristensen, G., Sorio, R., Vergote, I., Witteveen, P., Bamias, A., Pereira, D., Wimberger, P., Oaknin, A., Mirza, M.R., Follana, P., Bollag, D. and Ray-Coquard, I. (2014) Bevacizumab 
Combined with Chemotherapy for Platinum-Resistant Recurrent Ovarian Cancer: The AURELIA Open-Label Randomized Phase III Trial. Journal of Clinical Oncology, 32, 1302-1308. https://doi.org/10.1200/JCO.2013.51.4489

[55] Mayrbäurl, B., Giesinger, J.M., Burgstaller, S., Piringer, G., Holzner, B. and Thaler, J. (2016) Quality of Life across Chemotherapy Lines in Patients with Advanced Colorectal Cancer: A Prospective Single-Center Observational Study. Supportive Care in Cancer, 24, 667-674. https://doi.org/10.1007/s00520-015-2828-0

[56] Coleman, R.L. (2016) Insights into Strategies for Optimizing Ovarian Cancer Care. Nature Reviews Clinical Oncology, 13, 71-72. https://doi.org/10.1038/nrclinonc.2015.225

[57] Mansi, L., Demarchi, M., Bazan, F., Delroeux, D., Chaigneau, L., Thiery-Vuillemin, A., Kalbacher, E., et al. (2016) Impact of Chemotherapy beyond the Third Line in Patients with Recurrent Epithelial Ovarian Cancer. International Journal of Gynecologic Cancer, 26, 261-267. https://doi.org/10.1097/IGC.0000000000000592

[58] Viganó, A., Bruera, E., Jhangri, G.S., Newman, S.C., Fields, A.L. and Suarez-Almazor, M.E. (2000) Clinical Survival Predictors in Patients with Advanced Cancer. Archives of Internal Medicine, 160, 861-868. https://doi.org/10.1001/archinte.160.6.861

[59] Gramling, R., Stanek, S., Han, P.J., Duberstein, P., Quill, T.E., Temel, J.S., Alexander, S.C. anderson, W.G., Ladwig, S. and Norton, S.A. (2018) Distress Due to Prognostic Uncertainty in Palliative Care: Frequency, Distribution, and Outcomes among Hospitalized Patients with Advanced Cancer. Journal of Palliative Medicine, 21, 315-321. https://doi.org/10.1089/jpm.2017.0285

[60] Chu, C. anderson, R., White, N. and Stone, P. (2020) Prognosticating for Adult Patients with Advanced Incurable Cancer: A Needed Oncologist Skill. Current Treatment Options in Oncology, 21, Article No. 5. https://doi.org/10.1007/s11864-019-0698-2

[61] Temel, J.S., Greer, J.A., Admane, S., Gallagher, E.R., Jackson, V.A., Lynch, T.J., Lennes, I.T., Dahlin, C.M. and Pirl, W.F. (2011) Longitudinal Perceptions of Prognosis and Goals of Therapy in Patients with Metastatic Non-Small-Cell Lung Cancer: Results of a Randomized Study of Early Palliative Care. Journal of Clinical Oncology, 29, 2319-2326. https://doi.org/10.1200/JCO.2010.32.4459

[62] Mack, J.W., Wolfe, J., Cook, E.F., Grier, H.E., Cleary, P.D. and Weeks, J.C. (2007) Hope and Prognostic Disclosure. Journal of Clinical Oncology, 25, 5636-5642.

https://doi.org/10.1200/JCO.2007.12.6110

[63] Smith, T.J. and Bodurtha, J.N. (1995) Ethical Considerations in Oncology: Balancing the Interests of Patients, Oncologists, and Society. Journal of Clinical Oncology, 13, 2464-2470. https://doi.org/10.1200/JCO.1995.13.9.2464

[64] Dang, B.N., Westbrook, R.A., Njue, S.M., et al. (2017) Building Trust and Rapport Early in the New Doctor-Patient Relationship: A Longitudinal Qualitative Study. BMC Medical Education, 17, Article No. 32. https://doi.org/10.1186/s12909-017-0868-5

[65] Palaia, I., Tomao, F., Santangelo, G., Di Pinto, A., Sassu, C.M., Perniola, G., Musella, A., Di Donato, V., Giancotti, A. and Panici, P.B. (2019) The EOLO (End-of-Life Ovarian Cancer) Study: Approach to Ovarian Cancer Patients at the End of Life. Oncology, 97, 306-310. https://doi.org/10.1159/000501721

[66] Lennes, I.T., Temel, J.S., Hoedt, C., Meilleur, A. and Lamont, E.B. (2013) Predictors of Newly Diagnosed Cancer Patients' Understanding of the Goals of Their Care at Initiation of Chemotherapy. Cancer, 119, 691-699.

https://doi.org/10.1002/cncr.27787 
[67] Simpkin, A.L. and Armstrong, K.A. (2019) Communicating Uncertainty: A Narrative Review and Framework for Future Research. Journal of General Internal Medicine, 34, 2586-2591. https://doi.org/10.1007/s11606-019-04860-8

[68] Kiely, B.E., Soon, Y.Y., Tattersall, M.H. and Stockler, M.R. (2011) How Long Have I Got? Estimating Typical, Best-Case, and Worst-Case Scenarios for Patients Starting First-Line Chemotherapy for Metastatic Breast Cancer: A Systematic Review of Recent Randomized Trials. Journal of Clinical Oncology, 29, 456-463.

https://doi.org/10.1200/JCO.2010.30.2174

[69] Demirelli, B., Babacan, N.A., Ercelep, Ö., Öztürk, M.A., Kaya, S., Tanrıkulu, E., Khalil, S., Hasanov, R., Alan, Ö., Telli, T.A., Koca, S., Arıbal, M.E., Kuzan, B., Dane, F. and Yumuk, P.F. (2021) Modified Glasgow Prognostic Score, Prognostic Nutritional Index and ECOG Performance Score Predicts Survival Better than Sarcopenia, Cachexia and Some Inflammatory Indices in Metastatic Gastric Cancer. Nutrition and Cancer, 73, 230-238. https://doi.org/10.1080/01635581.2020.1749290

[70] Finlayson, C.S., Chen, Y.T. and Fu, M.R. (2015) The Impact of Patients' Awareness of Disease Status on Treatment Preferences and Quality of Life among Patients with Metastatic Cancer: A Systematic Review from 1997-2014. Journal of Palliative Medicine, 18, 176-186. https://doi.org/10.1089/jpm.2014.0222

[71] Shatri, H., Putranto, R., Irawan, C., Adli, M. and Elita, D. (2019) Characteristics of Palliative Patients, Insights of Patients and Families, and the Impact of Estimated Survival Time on Therapy Decisions. Acta Medica Indonesiana, 51, 151-157.

[72] Peele, P.B., Siminoff, L.A., Xu, Y. and Ravdin, P.M. (2005) Decreased Use of Adjuvant Breast Cancer Therapy in a Randomized Controlled Trial of a Decision Aid with Individualized Risk Information. Medical Decision Making, 25, 301-307. https://doi.org/10.1177/0272989X05276851

[73] Creutzfeldt, A., Suling, A., Oechsle, K., Mehnert, A., Atanackovic, D., Kripp, M., Arnold, D., Stein, A. and Quidde, J. (2016) Integrating Patient Reported Measures as Predictive Parameters into Decision Making about Palliative Chemotherapy: A Pilot Study. BMC Palliative Care, 15, Article No. 25.

https://doi.org/10.1186/s12904-016-0101-Z

[74] Shrestha, A., Martin, C., Burton, M., Walters, S., Collins, K. and Wyld, L. (2019) Quality of Life versus Length of Life Considerations in Cancer Patients: A Systematic literature Review. Psycho-Oncology, 28, 1367-1380.

https://doi.org/10.1002/pon.5054

[75] Younger, E., Jones, R.L., den Hollander, D., Soomers, V., Desar, I., Benson, C., Young, R.J., Oosten, A.W., de Haan, J.J., Miah, A., Zaidi, S., Gelderblom, H., Steeghs, N., Husson, O. and van der Graaf, W.T.A. (2021) Priorities and Preferences of Advanced Soft Tissue Sarcoma Patients Starting Palliative Chemotherapy: Baseline Results from the HOLISTIC Study. ESMO Open, 6, 100258.

https://doi.org/10.1016/j.esmoop.2021.100258

[76] Cardenas-Turanzas, M., Gaeta, S., Ashoori, A., Price, K.J. and Nates, J.L. (2011) Demographic and Clinical Determinants of Having Do Not Resuscitate Orders in the Intensive Care Unit of a Comprehensive Cancer Center. Journal of Palliative Medicine, 14, 45-50. https://doi.org/10.1089/jpm.2010.0165

[77] Ghandourh, W.A. (2016) Palliative Care in Cancer: Managing Patients' Expectations. Journal of Medical Radiation Sciences, 63, 242-257. https://doi.org/10.1002/jmrs.188

[78] Buckley de Meritens, A., Margolis, B., Blinderman, C., Prigerson, H.G., Maciejewski, P.K., Shen, M.J., Tergas, A.I., et al. (2017) Practice Patterns, Attitudes, and Barriers to Palliative Care Consultation by Gynecologic Oncologists. Journal of Oncol- 
ogy Practice, 13, e703-e711. https://doi.org/10.1200/JOP.2017.021048

[79] CAPC (2021) Center to Advance Palliative Care. About Palliative Care. https://www.capc.org/about/palliative-care

[80] Kobayashi, H., Tsuchiyama, K., Taga, M., Tokunaga, T., Ito, H. and Yokoyama, O. (2021) Impact of Self-Decision to Stop Cancer Treatment on Advanced Genitourinary Cancer Patients. Medicine, 100, e25397. https://doi.org/10.1097/MD.0000000000025397

[81] White, N., Reid, F., Harris, A., Harries, P. and Stone, P. (2016) A Systematic Review of Predictions of Survival In Palliative Care: How Accurate Are Clinicians and Who Are the Experts? PLoS ONE, 11, e0161407. https://doi.org/10.1371/journal.pone.0161407

[82] Utsumi, F., Kajiyama, H., Niimi, K., Sekiya, R., Sakata, J., Suzuki, S., Kikkawa, F., et al. (2017) Clinical Significance and Predicting Indicators of Post-Cancer-Treatment Survival in Terminally Ill Patients with Ovarian Cancer. Journal of Obstetrics and Gynaecology Research, 43, 365-370. https://doi.org/10.1111/jog.13219

[83] Wright, A.A., Keating, N.L., Ayanian, J.Z., Chrischilles, E.A., Kahn, K.L., Ritchie, C.S., Weeks, J.C., Earle, C.C. and Landrum, M.B. (2016) Family Perspectives on Aggressive Cancer Care near the End of Life. JAMA, 315, 284-292. https://doi.org/10.1001/jama.2015.18604

[84] Gramling, R., Fiscella, K., Xing, G., Hoerger, M., Duberstein, P., Plumb, S., Mohile, S., Fenton, J.J., Tancredi, D.J., Kravitz, R.L. and Epstein, R.M. (2016) Determinants of Patient-Oncologist Prognostic Discordance in Advanced Cancer. JAMA Oncology, 2, 1421-1426. https://doi.org/10.1001/jamaoncol.2016.1861

[85] Matsuyama, R., Reddy, S. and Smith, T.J. (2006) Why Do Patients Choose Chemotherapy near the End of Life? A Review of the Perspective of Those Facing Death from Cancer. Journal of Clinical Oncology, 24, 3490-3496. https://doi.org/10.1200/JCO.2005.03.6236

[86] Ikander, T., Jeppesen, S.S., Hansen, O., Raunkiær, M. and Dieperink, K.B. (2021) Patients and Family Caregivers Report High Treatment Expectations during Palliative Chemotherapy: A Longitudinal Prospective Study. BMC Palliative Care, 20, Article No. 37. https://doi.org/10.1186/s12904-021-00731-4

[87] Houck, K., Gallant, J., Avis, N., Fuller, A.F. and Goodman, A. (1999) Quality of Life in Advanced Cancer Patients: Addressing Specific Concerns. Journal of Palliative Medicine, 2, 397-402. https://doi.org/10.1089/jpm.1999.2.397

[88] Widera, E.W., Rosenfeld, K.E., Fromme, E.K., Sulmasy, D.P. and Arnold, R.M. (2011) Approaching Patients and Family Members Who Hope for a Miracle. Journal of Pain and Symptom Management, 42, 119-125. https://doi.org/10.1016/j.jpainsymman.2011.03.008

[89] Zier, L.S., Burack, J.H., Micco, G., Chipman, A.K., Frank, J.A. and White, D.B. (2009) Surrogate Decision Makers' Responses to Physicians' Predictions of Medical Futility. Chest, 136, 110-117. https://doi.org/10.1378/chest.08-2753

[90] Fahmy, D. (2018) Key Findings about Americans' belief in God. Pew Research Center, Washington DC.

https://www.pewresearch.org/fact-tank/2018/04/25/key-findings-about-americansbelief-in-god

[91] Jørgensen, K.J., Hróbjartsson, A. and Gøtzsche, P.C. (2009) Divine Intervention? A Cochrane Review on Intercessory Prayer Gone beyond Science and Reason. Journal of Negative Results in Biomedicine, 8, Article No. 7. https://doi.org/10.1186/1477-5751-8-7 
[92] Roberts, J.A., Brown, D., Elkins, T. and Larson, D.B. (1997) Factors Influencing Views of Patients with Gynecologic Cancer about End-of-Life Decisions. American Journal of Obstetrics \& Gynecology, 176, 166-172. https://doi.org/10.1016/S0002-9378(97)80030-0

[93] Henselmans, I., Brugel, S.D., de Haes, H., Wolvetang, K., de Vries, L.M., Pieterse, A.H., Baas-Thijssen, M.C., de Vos, F.Y.F., van Laarhoven, H.W.M. and Smets, E.M.A. (2019) Promoting Shared Decision Making in Advanced Cancer: Development and Piloting of a Patient Communication Aid. Patient Education and Counseling, 102, 916-923. https://doi.org/10.1016/j.pec.2018.12.018

[94] Glare, P., Virik, K., Jones, M., Hudson, M., Eychmuller, S., Simes, J. and Christakis, N. (2003) A Systematic Review of Physicians' Survival Predictions in Terminally Ill Cancer Patients. BMJ, 327, Article No. 195. https://doi.org/10.1136/bmj.327.7408.195

[95] Keating, N.L., Landrum, M.B., Rogers Jr., S.O., Baum, S.K., Virnig, B.A., Huskamp, H.A., Kahn, K.L., et al. (2010) Physician Factors Associated with Discussions about End-of-Life Care. Cancer. Interdisciplinary International Journal of the American Cancer Society, 116, 998-1006. https://doi.org/10.1002/cncr.24761

[96] Martoni, A.A., Tanneberger, S. and Mutri, V. (2007) Cancer Chemotherapy near the End of Life: The Time Has Come to Set Guidelines for Its Appropriate Use. Tumori, 93, 417-422. https://doi.org/10.1177/030089160709300502

[97] Srivastava, R. (2011) Critical Conversations: Navigating between Hope and Truth. The Lancet, 378, 1213-1214. https://doi.org/10.1016/S0140-6736(11)61530-4

[98] Balboni, T., Balboni, M., Paulk, M.E., Phelps, A., Wright, A., Peteet, J., Block, S., Lathan, C., Vanderweele, T. and Prigerson, H. (2011) Support of Cancer Patients' Spiritual Needs and Associations with Medical Care Costs at the End of Life. Cancer, 117, 5383-5391. https://doi.org/10.1002/cncr.26221

[99] Buiting, H.M., Rurup, M.L., Wijsbek, H., van Zuylen, L. and den Hartogh, G. (2011) Understanding Provision of Chemotherapy to Patients with End Stage Cancer: Qualitative Interview Study. BMJ (Clinical Research ed.), 342, d1933.

https://doi.org/10.1136/bmj.d1933

[100] Emanuel, E.J., Levinsky, N.G., Gazelle, G., Saynina, O. and Ash, A.S. (2003) Chemotherapy Use among Medicare Beneficiaries at the End of Life. Annals of Internal Medicine, 138, 639-643. https://doi.org/10.7326/0003-4819-138-8-200304150-00011

[101] Massa, I., Nanni, O., Foca, F., Maltoni, M., Derni, S., Gentili, N., Frassineti, G.L., Casadei Gardini, A., Valgiusti, M., Amadori, D., Prati, E., Altini, M., Gallegati, D. and Sansoni, E. (2018) Chemotherapy and Palliative Care near End-of Life: Examining the Appropriateness at a Cancer Institute for Colorectal Cancer Patients. BMC Palliative Care, 17, Article No. 86. https://doi.org/10.1186/s12904-018-0339-8

[102] Yeh, J.C., Knight, L.S., Kane, J., Doberman, D.J., Gupta, A. and Smith, T.J. (2019) Has There Been a Shift in Use of Subacute Rehabilitation Instead of Hospice Referral Since Immunotherapy Has Become Available? Journal of Oncology Practice, 15, e849-e855. https://doi.org/10.1200/JOP.19.00044

[103] Lang, F. and Quill, T. (2004) Making Decisions with Families at the End of Life. American Family Physician, 70, 719-723.

[104] Parker, S.M., Clayton, J.M., Hancock, K., Walder, S., Butow, P.N., Carrick, S., Currow, D., Ghersi, D., Glare, P., Hagerty, R. and Tattersall, M.H. (2007) A Systematic Review of Prognostic/End-of-Life Communication with Adults in the Advanced Stages of a Life-Limiting Illness: Patient/Caregiver Preferences for the Content, Style, and Timing of Information. Journal of Pain and Symptom Management, 34, 
81-93. https://doi.org/10.1016/j.jpainsymman.2006.09.035

[105] Norton, S.A., Metzger, M., DeLuca, J., Alexander, S.C., Quill, T.E. and Gramling, R. (2013) Palliative Care Communication: Linking Patients' Prognoses, Values, and Goals of Care. Research in Nursing \& Health, 36, 582-590.

https://doi.org/10.1002/nur.21563

[106] Christakis, N.A. and Lamont, E.B. (2000) Extent and Determinants of Error in Doctors' Prognoses in Terminally Ill Patients: Prospective Cohort Study. BMJ (Clinical Research ed.), 320, 469-472. https://doi.org/10.1136/bmj.320.7233.469

[107] Back, A.L. anderson, W.G., Bunch, L., Marr, L.A., Wallace, J.A., Yang, H.B. and Arnold, R.M. (2008) Communication about Cancer near the End of Life. Cancer, 113, 1897-1910. https://doi.org/10.1002/cncr.23653

[108] Winkler, E.C., Hiddemann, W. and Marckmann, G. (2012) Evaluating a Patient's Request for Life-Prolonging Treatment: An Ethical Framework. Journal of Medical Ethics, 38, 647-651. https://doi.org/10.1136/medethics-2011-100333

[109] White, N., Harries, P., Harris, A.J., Vickerstaff, V., Lodge, P., McGowan, C., Stone, P., et al. (2018) How Do Palliative Care Doctors Recognise Imminently Dying Patients? A Judgement Analysis. BMJ Open, 8, e024996.

https://doi.org/10.1136/bmjopen-2018-024996

[110] Adamson, M., Choi, K., Notaro, S. and Cotoc, C. (2018) The Doctor-Patient Relationship and Information-Seeking Behavior: Four Orientations to Cancer Communication. Journal of Palliative Care, 33, 79-87.

https://doi.org/10.1177/0825859718759881

[111] Dzeng, E., Colaianni, A., Roland, M., Chander, G., Smith, T.J., Kelly, M.P., Levine, D., et al. (2015) Influence of Institutional Culture and Policies on Do-Not-Resuscitate Decision Making at the End of Life. JAMA Internal Medicine, 175, 812-819. https://doi.org/10.1001/jamainternmed.2015.0295

[112] Cherny, N.I., Catane, R. and European Society of Medical Oncology Taskforce on Palliative and Supportive Care (2003) Attitudes of Medical Oncologists toward Palliative Care for Patients with Advanced and Incurable Cancer: Report on a Survey by the European Society of Medical Oncology Taskforce on Palliative and Supportive Care. Cancer, 98, 2502-2510. https://doi.org/10.1002/cncr.11815

[113] Zimmermann, C., Swami, N., Krzyzanowska, M., Hannon, B., Leighl, N., Oza, A., Donner, A., et al. (2014) Early Palliative Care for Patients with Advanced Cancer: A Cluster-Randomised Controlled Trial. The Lancet, 383, 1721-1730. https://doi.org/10.1016/S0140-6736(13)62416-2

[114] Hugar, L.A., Wulff-Burchfield, E.M., Winzelberg, G.S., et al. (2021) Incorporating Palliative Care Principles to Improve Patient Care and Quality of Life in Urologic Oncology. Nature Reviews Urology, 18, 623-635.

https://doi.org/10.1038/s41585-021-00491-z

[115] Brown, A.J., Shen, M.J., Urbauer, D., Taylor, J., Parker, P.A., Carmack, C., Ramondetta, L., et al. (2016) Room for Improvement: An Examination of Advance Care Planning Documentation among Gynecologic Oncology Patients. Gynecologic Oncology, 142, 525-530. https://doi.org/10.1016/j.ygyno.2016.07.010

[116] Kaasa, S., Loge, J.H., Aapro, M., Albreht, T. anderson, R., Bruera, E., Deliens, L., et al. (2018) Integration of Oncology and Palliative Care: A Lancet Oncology Commission. The Lancet Oncology, 19, e588-e653.

https://doi.org/10.1016/S1470-2045(18)30415-7

[117] Salins, N., Ghoshal, A., Hughes, S., et al. (2020) How Views of Oncologists and Haematologists Impacts Palliative Care Referral: A Systematic Review. BMC Pallia- 
tive Care 19, 175. https://doi.org/10.1186/s12904-020-00671-5

[118] Kash, K.M., Holland, J.C., Breitbart, W., Berenson, S., Dougherty, J., Ouellette-Kobasa, S. and Lesko, L. (2000) Stress and Burnout in Oncology. Oncology (Williston Park), 14, 1621-1633.

[119] De la Fuente-Solana, E.I., Pradas-Hernández, L., Ramiro-Salmerón, A., SuleimanMartos, N., Gómez-Urquiza, J.L., Albendín-García, L. and Cañadas-De la Fuente, G.A. (2020) Burnout Syndrome in Paediatric Oncology Nurses: A Systematic Review and Meta-Analysis. Healthcare (Basel), 8, Article No. 309. https://doi.org/10.3390/healthcare8030309

[120] Shayne, M. and Quill, T.E. (2012) Oncologists Responding to Grief. Archives of Internal Medicine, 172, 966-967. https://doi.org/10.1001/archinternmed.2012.2035

[121] Díaz-Montes, T.P., Johnson, M.K., Giuntoli, R.L. and Brown, A.J. (2013) Importance and Timing of End-of-Life Care Discussions among Gynecologic Oncology Patients. American Journal of Hospice and Palliative Medicine ${ }^{\circledR}, 30,59-67$. https://doi.org/10.1177/1049909112444156

[122] Mullen, M.M., Cripe, J.C. and Thaker, P.H. (2019) Palliative Care in Gynecologic Oncology. Obstetrics and Gynecology Clinics, 46, 179-197. https://doi.org/10.1016/j.ogc.2018.10.001

[123] Einav, L., Finkelstein, A., Mullainathan, S. and Obermeyer, Z. (2018) Predictive Modeling of US Health Care Spending in Late Life. Science, 360, 1462-1465. https://doi.org/10.1126/science.aar5045

[124] Wu, E., Rogers, A., Ji, L., Sposto, R., Church, T., Roman, L., Lin, Y.G., et al. (2015) Escalation of Oncologic Services at the End of Life among Patients with Gynecologic Cancer at an Urban, Public Hospital. Journal of Oncology Practice, 11, e163-e169. https://doi.org/10.1200/JOP.2014.001529

[125] Bliton, J.N., Parides, M., Muscarella, P., Papalezova, K.T. and In, H. (2021) Understanding Racial Disparities in Gastrointestinal Cancer Outcomes: Lack of Surgery Contributes to Lower Survival in African American Patients. Cancer Epidemiology, Biomarkers \& Prevention: A Publication of the American Association for Cancer Research, 30, 529-538. https://doi.org/10.1158/1055-9965.EPI-20-0950

[126] Brule, S.Y., Al-Baimani, K., Jonker, H., Zhang, T., Nicholas, G., Goss, G., Laurie, S.A. and Wheatley-Price, P. (2016) Palliative Systemic Therapy for Advanced Non-Small Cell Lung Cancer: Investigating Disparities between Patients Who Are Treated versus Those Who Are Not. Lung Cancer, 97, 15-21. https://doi.org/10.1016/j.lungcan.2016.04.007

[127] Mullins, M.A., Ruterbusch, J.J., Clarke, P., Uppal, S., Wallner, L.P. and Cote, M.L. (2021) Trends and Racial Disparities in Aggressive End-of-Life Care for a National Sample of Women with Ovarian Cancer. Cancer, 127, 2229-2237. https://doi.org/10.1002/cncr.33488

[128] Trevino, K.M., Zhang, B., Shen, M.J. and Prigerson, H.G. (2016) Accuracy of Advanced Cancer Patients' Life Expectancy Estimates: The Role of Race and Source of Life Expectancy Information. Cancer, 122, 1905-1912.

https://doi.org/10.1002/cncr.30001

[129] Perry, L.M., Walsh, L.E., Horswell, R., et al. (2021) Racial Disparities in End-of-Life Care between Black and White Adults with Metastatic Cancer. Journal of Pain and Symptom Management, 61, 342-349.E1. https://doi.org/10.1016/j.jpainsymman.2020.09.017

[130] Penner, L.A., Dovidio, J.F., Gonzalez, R., et al. (2016) The Effects of Oncologist Implicit Racial Bias in Racially Discordant Oncology Interactions. Journal of Clinical 
Oncology, 34, 2874-2880. https://doi.org/10.1200/JCO.2015.66.3658

[131] Von Roenn, J.H. (2019) Is Implicit Bias Contributing to Time Disparities in Goals-of-Care Conversations with Minority Patients? A Conversation with Cardinale B. Smith, MD, PhD. The ASCO Post.

https://ascopost.com/news/september-2019/is-implicit-bias-contributing-to-time-di sparities-in-conversations-with-minority-pa

[132] Murphy, M.M., Simons, J.P., Ng, S.C., McDade, T.P., Smith, J.K., Shah, S.A., Zhou, Z., Earle, C.C. and Tseng, J.F. (2009) Racial Differences in Cancer Specialist Consultation, Treatment, and Outcomes for Locoregional Pancreatic Adenocarcinoma. Annals of Surgical Oncology, 16, 2968-2977. https://doi.org/10.1245/s10434-009-0656-5

[133] Rajagopal, P.S., Nipp, R.D. and Selvaggi, K.J. (2014) Chemotherapy for Advanced Cancers. Annals of Palliative Medicine, 3, 203-228.

[134] Tsubamoto, H., Ito, Y., Kanazawa, R., Wada, R., Hosoda, Y., Honda, O., Shibahara, H., et al. (2014) Benefit of Palliative Chemotherapy and Hospice Enrollment in Late-Stage Ovarian Cancer Patients. Journal of Obstetrics and Gynaecology Research, 40, 1399-1406. https://doi.org/10.1111/jog.12320

[135] Murakawa, Y., Sakayori, M. and Otsuka, K. (2019) Impact of Palliative Chemotherapy and Best Supportive Care on Overall Survival and Length of Hospitalization in Patients with Incurable Cancer: A 4-Year Single Institution Experience in Japan. BMC Palliative Care, 18, Article No. 45.

https://doi.org/10.1186/s12904-019-0428-3

[136] Donnelly, S., Prizeman, G., Coimín, D.Ó., et al. (2018) Voices That Matter: End-ofLife Care in Two Acute Hospitals from the Perspective of Bereaved Relatives. BMC Palliative Care, 17, Article No. 117. https://doi.org/10.1186/s12904-018-0365-6

[137] Epstein, R.M., Alper, B.S. and Quill, T.E. (2004) Communicating Evidence for Participatory Decision Making. JAMA, 291, 2359-2366.

https://doi.org/10.1001/jama.291.19.2359

[138] Epstein, R.M., Duberstein, P.R., Fenton, J.J., Fiscella, K., Hoerger, M., Tancredi, D.J., Xing, G., Gramling, R., Mohile, S., Franks, P., Kaesberg, P., Plumb, S., Cipri, C.S., Street, R.L., Shields, C.G., Back, A.L., Butow, P., Walczak, A., Tattersall, M., Venuti, A., Sullivan, P., Robinson, M., Hoh, B., Lewis, L. and Kravitz, R.L. (2017) Effect of a Patient-Centered Communication Intervention on Oncologist-Patient Communication, Quality of Life, and Health Care Utilization in Advanced Cancer: The VOICE Randomized Clinical Trial. JAMA Oncology, 3, 92-100. https://doi.org/10.1001/jamaoncol.2016.4373

[139] Foote, J., Lopez-Acevedo, M., Samsa, G., Lee, P.S., Kamal, A.H., Secord, A.A. and Havrilesky, L.J. (2018) Predicting 6- and 12-Month Risk of Mortality in Patients with Platinum-Resistant Advanced-Stage Ovarian Cancer: Prognostic Model to Guide Palliative Care Referrals. International Journal of Gynecologic Cancer, 28, 302-307. https://doi.org/10.1097/IGC.0000000000001182

[140] Scarborough, B.M. and Smith, C.B. (2018) Optimal Pain Management for Patients with Cancer in the Modern Era. CA: A Cancer Journal for Clinicians, 68, 182-196. https://doi.org/10.3322/caac.21453

[141] Walling, A.M., Asch, S.M., Lorenz, K.A., et al. (2012) The Quality of Supportive Care among Inpatients Dying with Advanced Cancer. Supportive Care in Cancer, 20, 2189-2194. https://doi.org/10.1007/s00520-012-1462-3

[142] Carolan, C.M., Smith, A., Davies, G.R. and Forbat, L. (2018) Seeking, Accepting and Declining Help for Emotional Distress in Cancer: A Systematic Review and The- 
matic Synthesis of Qualitative Evidence. European Journal of Cancer Care, 27, e12720. https://doi.org/10.1111/ecc.12720

[143] Spiegel, D. (2012) Mind Matters in Cancer Survival. Psycho-Oncology, 21, 588-593. https://doi.org/10.1002/pon.3067

[144] Meropol, N., Egleston, B.L., Buzaglo, J.S., Benson, A.B., Cegala, D.J., Diefenbach, M.A., Fleisher, L., Miller, S.M., Sulmasy, D.P., Weinfurt, K.P. and CONNECT Study Research Group (2008) Cancer Patient Preferences for Quality and Length of Life. Cancer, 113, 3459-3466. https://doi.org/10.1002/cncr.23968

[145] Chan, W.L., Lam, K.O., Siu, W.K. and Yuen, K.K. (2016) Chemotherapy at End-of-Life: An Integration of Oncology and Palliative Team. Supportive Care in Cancer, 24, 1421-1427. https://doi.org/10.1007/s00520-015-3031-Z

[146] Greer, J.A., Pirl, W.F., Jackson, V.A., Muzikansky, A., Lennes, I.T., Heist, R.S., Gallagher, E.R. and Temel, J.S. (2012) Effect of Early Palliative Care on Chemotherapy Use and End-of-Life Care in Patients with Metastatic Non-Small-Cell Lung Cancer. Journal of Clinical Oncology, 30, 394-400. https://doi.org/10.1200/JCO.2011.35.7996

[147] Lee, S.W., Jho, H.J., Baek, J.Y., Shim, E.K., Kim, H.M., Ku, J.Y., Nam, E.J., Chang, Y.J., Choi, H.J. and Kim, S.Y. (2018) Outpatient Palliative Care and Aggressiveness of End-of-Life Care in Patients with Metastatic Colorectal Cancer. American Journal of Hospice and Palliative Care, 35, 166-172. https://doi.org/10.1177/1049909116689459

[148] Lees, C., Weerasinghe, S., Lamond, N., Younis, T. and Ramjeesingh, R. (2019) Palliative Care Consultation and Aggressive Care at End of Life in Unresectable Pancreatic Cancer. Current Oncology (Toronto, Ont.), 26, 28-36. https://doi.org/10.3747/co.26.4389

[149] Morita, T., Akechi, T., Ikenaga, M., et al. (2005) Late Referrals to Specialized Palliative Care Service in Japan. Journal of Clinical Oncology, 23, 2637-2644. https://doi.org/10.1200/JCO.2005.12.107

[150] Rego, F., Gonçalves, F., Moutinho, S., et al. (2020) The Influence of Spirituality on Decision-Making in Palliative Care Outpatients: A Cross-Sectional Study. BMC Palliative Care, 19, Article No. 22. https://doi.org/10.1186/s12904-020-0525-3

[151] Saha, S., Beach, M.C. and Cooper, L.A. (2008) Patient Centeredness, Cultural Competence and Healthcare Quality. Journal of the National Medical Association, 100, 1275-1285. https://doi.org/10.1016/S0027-9684(15)31505-4

[152] Childers, J.W., Back, A.L., Tulsky, J. and Arnold, R.M. (2017) REMAP: A Framework for Goals of Care Conversations. Journal of Oncology Practice, 13, e844-e850. https://doi.org/10.1200/JOP.2016.018796

[153] VitalTalk (2019) Addressing Goals of Care: Using the REMAP Tool. https://www.vitaltalk.org/guides/transitionsgoals-of-care

[154] Messerotti, A., Banchelli, F., Ferrari, S., et al. (2020) Investigating the Association between Physicians Self-Efficacy Regarding Communication Skills and Risk of "Burnout". Health and Quality of Life Outcomes, 18, Article No. 271.

https://doi.org/10.1186/s12955-020-01504-y 